С.О. Щербінін, О.В. Беспалько, М.В. Гарячий, Ю.Р. Михальчук

Харківський наиіональний університет Повітряних Сил ім. І. Кожедуба, Харків

\title{
МОДЕЛЬ СИСТЕМИ ВОЄННО-НАУКОВОЇ ІНФОРМАЦІї ЗБРОЙНИХ СИЛ УКРАЇНИ
}

\begin{abstract}
У роботі розглядаються питання інформачійного забезпечення наукової $i$ науково-технічної діяльності НАТО, збройних сил США та Збройних Сил України. Наведений аналіз структури інформаційного забезпечення наукової і науково-технічної діяльності НАТО та збройних сил США. За результатами наведеного аналізу визначено недоцільність прямого копіювання системи воєнно-наукової інформації в систему воєнно-наукової інформації Збройних Сил Украӥни. На основі аналізу керівних документів та з метою уніфікації поняття, щуо застосовуються в НАТО, збройних силах США та Україні для інформації, направленої на забезпечення наукових досліджень в Збройних Силах України, запропоновано використовувати поняття “воєнно-наукова інформація”. Запропонована в роботі модель системи воєннонаукової інформачії дає можливість розділити вертикаль інформачійного забезпечення наукової $і$ науковотехнічної діяльності на структурні одиниці за функиіональним характером, визначити ієрархію між основними елементами системи воєнно-наукової інформації, розмежувати сфери відповідальності органів військового управління, встановити напрямки взаємозв'язків між основними елементами системи воєннонаукової інформації та в подальшому дослідити ефективність ї̈ функиіонування.
\end{abstract}

Ключові слова: інформація, воєнно-наукова інформація, інформаційне забезпечення, технічна інформація, наукова і науково-технічна діяльність.

\section{Вступ}

Постановка проблеми. На сьогоднішній день існує ряд суттєвих відмінностей між структурою військових відомств збройних сил країн світу, але основні та часткові завдання, що виконують ці відомства, залишаються незмінними та мають статус аксіоми.

Суттєвою відмінністю структури Збройних Сил України від структури збройних сил Сполучених штатів Америки (США) та інших країн-членів організації Північно атлантичного договору (НАТО) $є$ відсутність ії розподілення на цивільну, військову та допоміжну структуру, тобто структура Збройних Сил України є військово-цивільна.

Цей факт сам по собі не є негативною або позитивною рисою, але вносить суттєві зміни в структуру збройних сил щодо розподілу завдань між іiі структурними елементами.

Зважаючи на те, що Україна та Збройні Сили України як іiі невід'ємна складова спрямована на вступ до НАТО та імплементує у свою діяльність стандарти країн-членів НАТО, слід очікувати поступовий перехід від військово-цивільної структури Збройних Сил України до розподіленої структури на військову та цивільну. Перші зрушення в цьому напрямку вже помітні на фоні реформування Міністерства оборони (МО) України за цивільною структурою.
Ще однією відмінністю структури Збройних Сил України $є$ наявність в ній вищих військових навчальних закладів (ВВНЗ) та наукових установ (НУ) 3 великим науковим потенціалом, що проводять фундаментальні та прикладні дослідження у технічній та військовій сфері. Цей факт не є негативною рисою Збройних Сил України, а навпаки являється позитивним симбіозом великого наукового потенціалу та досвіду керівництва військовими організаційними структурами. Наявність таких структур вимагає не прямого переймання досвіду країнчленів НАТО з точки зору наукової i науковотехнічної діяльності (НіНТД) та зміщує акцент від цивільного управління всіма видами на НіНТД, що має місце наприклад у структурі збройних сил США, до військово-цивільного.

Основною проблемою трансформації досвіду 3 цивільної структури до військово-цивільної структури $є$ формування завдань підрозділів щодо всіх видів забезпечення НіНТД з урахуванням військової специфіки в умовах збройної агресії.

На жаль, Україна сьогодні знаходиться саме в таких умовах, тому питання розподілу завдань забезпечення НіНТД $є$ дуже актуальними. Втрата будь-якої складової такого забезпечення критична.

Аналіз останніх досліджень і публікацій. Аналіз керівних документів [1-3] за напрямом НіНТД вказує на їх часткову недосконалість щодо всебічного забезпечення НіНТД. 
Так у 2016 році було відмінено [4, додаток п. 46] наказ Міністра оборони України від 27.09.2000 № 315 “Про затвердження Положення про науково-інформаційну діяльність у Збройних Силах України”, що спричинило правовий колапс в питанні інформаційного забезпечення НіНТД щодо механізмів взаємодії та структури підрозділів інформаційного забезпечення. Поглибленням правового колапсу стало прийняття наказу Міністерства оборони від 23.02.2018 № 82 "Про затвердження Типових нормативів для розроблення штатів (штатних розписів) вищих військових навчальних закладів, військових навчальних підрозділів закладів вищої освіти та військових ліцеїв" [5], який скасував в складі ВВНЗ основний структурний підрозділ відділення військово-технічної інформації. При цьому завдання щодо інформаційного забезпечення НіНТД згідно припущення щодо аксіомності завдань в збройних силах не зникли. Таким чином, було втрачено спеціалізований підрозділ інформаційного забезпечення. Це призвело до зниження ефективності та якості інформаційного забезпечення НіНТД всіх ВВНЗ Збройних Сил України, а також були втрачені взаємозв'язки між структурами, що займалися інформаційним забезпеченням НіНТД. Вкрай тяжким став стан $з$ виданням наукових фахових видань. Додатковою проблемою також стала відсутність цільового фінансування за цим напрямом. Цим наказом також було зруйновано систему ефективного запобігання та виявлення академічного плагіату в наукових виданнях та роботах здобувачів наукових ступенів доктор філософії та доктор наук у ВВНЗ. Виконання завдань щодо інформаційного забезпечення НіНТД було покладено на науково-організаційний підрозділ, який є єдиним підрозділом у ВВНЗ, що здійснює науково-організаційну діяльність. Однак об’єм інформації та необхідний час на її обробку не може бути компенсований за рахунок науковоорганізаційного підрозділу у зв'язку з малою штатною чисельністю, що визначається не кількістю задач та/або кількістю наукових та науковопедагогічних працівників ВВНЗ, а кількістю тих, хто навчається.

Таким чином, існує наукове завдання щодо створення моделі системи воєнно-наукової інформації Збройних Сил України, що дасть можливість дослідити взаємозв'язки між елементами системи та розмежувати сфери відповідальності органів військового управління щодо інформаційного забезпечення НіНТД Збройних Сил України.

Мета статті - формування моделі воєннонаукової інформації Збройних Сил України, що враховує досвід провідних країн членів НАТО та відповідає військово-цивільній структурі побудови Збройних Сил України.

\section{Виклад основного матеріалу}

На сьогодні в країнах світу існують різні визначення поняття інформації, направленої на забезпечення наукових досліджень, що призводить до розбіжностей в їх тлумаченні представниками інших країн.

Так у збройних силах США застосовується визначення технічна інформація [6]. В Україні цьому поняттю відповідає поняття науково-технічна інформація [7; 10], але, на думку авторів, для інформаційного забезпечення НіНТД саме Збройних Сил України більш доцільно використовувати поняття “воєнно-наукова інформація" у наступному визначенні.

Воєнно-наукова інформація (BНI) - це документовані або публічно оголошені відомості в галузі воєнної науки, гуманітарних, технічних і природничих наук, які використовуються в інтересах розвитку воєнної теорії й практики, озброєння та військової техніки (ОВТ), інших засобів матеріальнотехнічного забезпечення Збройних Сил України.

Тому в подальшому в роботі для поняття "наукової (науково-технічної, технічної) інформації” буде використовуватися поняття “воєнно-наукова інформація".

Аналіз структури НАТО вказує, що з метою подальшого розвитку в їі адміністративній структурі передбачено відділ нових викликів безпеці (Emerging Security Challenges Division) [11], в рамках якого функціонує дві програми з розробки нових передових технологій та можливостей для захисту військ та цивільного населення від терористичних атак та інших асиметричних загроз (Defence Against Terrorism Programme of Work) та 3 фінансування, експертних консультацій та підтримки індивідуалізованої діяльності, пов'язаної з цивільною безпекою між державами-членами НАТО та странами партнерами за допомогою наукових досліджень, технологічних інновацій та обміном знаннями (Science for Peace and Security Programme). Як основна організація, що втілює в життя наукові та технологічні дослідження, функціонує організація НАТО з науки та технологій (NATO Science and Technology Organization), що об’єднує Раду з науки та технологій (Science and Technology Board), Програмний офic для сумісної науково-технічної діяльності (Programme Office for Collaborative S\&T) та Центр морських досліджень та експериментів (Centre for Maritime Research and Experimentation).

Наявність таких організаційних структур свідчить про неабияку зацікавленість НАТО до подальшого розвитку та втілення нових результатів досліджень. Слід зазначити, що дані структурні елементи НАТО є повністю цивільними. 
Розглядаючи збройні сили США як оптимальну 3 точки зору своєї функціональності структуру в складі НАТО, слід зазначити, що в її структурі також є підрозділи, що направленні на розвиток [6].

В МО США з метою розвитку нових технологій та інновацій передбачено посаду заступника МО США $з$ досліджень та розробок (Under Secretary of Defense for Research and Engineering (USD (R\&E)), якому підпорядковується десять окремих структур, що займаються розвитком та втіленням в кінцевий продукт результатів наукових досліджень.

3 метою інформаційного забезпечення в структурі МО США функціонує Центр технічної інформації (Defense Technical Information Center (DTIC)).

DTIC забезпечує підтримку USD (R\&E) з питань актуальних загроз та загроз, що з'являються, актуальних та нових можливостей озброєння та військової техніки за допомогою розвитку нових інженерних технологій.

Основними завданнями DTIC є:

зберігання та розповсюдження результатів впроваджених досліджень;

надання бази даних, що дозволяє дослідним та дослідно-конструкторським підприємствам прискорювати розробку технологій;

стимулювання інновації за допомогою надання доступу дослідним та дослідно-конструкторським підприємствам до досліджень, що фінансуються за рахунок МО США;

мінімізація вартості продукції, що фінансується МО США, за допомогою аналізу даних про фінансування, незавершених робіт, незалежних досліджень та розробок для виявлення проблем та шляхів подальшого розвитку.

3 метою аналізу великих об’ємів даних, що мають місце під час діяльності DTIC, йому підпорядковуються Центри інформаційного аналізу МО США (Basic Centers of Operations and a multiple award contract (IAC MAC)), що проводять фінансування технічних досліджень та аналізу даних на суму більше 28 мільярдів доларів.

IAC MAC забезпечують необхідний технічний аналіз та підтримку даних для різнорідної клієнтської бази, що охоплює бойові командування, канцелярію Міністра оборони, оборонні агентства та військові служби.

Слід зазначити, що ця структура є повністю цивільною.

Виходячи зі структури МО США видно, що питанням інформаційного забезпечення НіНТД приділяється валика увага. Тому розвиток цього напрямку забезпечення в Збройних Силах України в умовах переходу на стандарти країн-членів НАТО $\epsilon$ актуальним.

Зважаючи на те, що структура Збройних Сил України має військово-цивільний характер, то не- можливо повністю застосувати модель побудови інформаційного забезпечення Збройних Сил України на основі моделі НАТО або збройних сил США. 3 метою врахування особливостей побудови структури Збройних Сил України пропонується скомпілювати систему інформаційного забезпечення збройних сил США з існуючою системою управління НіНТД Збройних Сил України.

Так, пропонується створити систему ВНІ, що наведена на рис. 1.

Елементи системи ВНI розділені на:

керівний орган системи BHI;

орган узагальнення та каталогізації ВНI;

суб'єкти системи ВНI;

підрозділи узагальнення та каталогізації ВНI

ВВН3 та НУ;

суб'єкти постачання ВНI;

об'єкти системи ВНI.

Керівництво інформаційним забезпеченням НіНТД МО України здійснює заступник МО України відповідно до розподілу повноважень через департамент військової освіти та науки МО України (ДВОН).

Основними завданнями ДВОН є:

організація та забезпечення функціонування єдиних принципів реалізації наукової (науковотехнічної) політики в МО України на основі законодавства України;

надання баз даних, що дозволяють дослідним та дослідно-конструкторським підприємствам прискорювати розробку технологій;

стимулювання інновацій за допомогою надання доступу дослідним та дослідно-конструкторським підприємствам до досліджень, що фінансуються за рахунок МО України;

мінімізація вартості продукції, що фінансується МО України, за допомогою даних аналізу незавершених робіт та незалежних досліджень та розробок;

організація та підтримання інформаційних зв'язків і контактів з інформаційними органами (системами) збройних сил країн-членів НАТО та іншими державами у рамках міжнародного співробітництва.

Керівництво інформаційним забезпеченням НіНТД Збройних Сил України як військовоцивільною структурою здійснює заступник начальника генерального штабу (ГШ) Збройних Сил України відповідно до розподілу повноважень через Воєнно-наукове управління ГШ Збройних Сил України.

Основними завданнями ВНУ ГШ Збройних Сил України є:

організація та забезпечення функціонування єдиних принципів реалізації наукової (науковотехнічної) політики в Збройних Силах України на основі законодавства України;

координація інформаційного забезпечення НіНТД у Збройних Силах України i науковометодичне керівництво нею; 


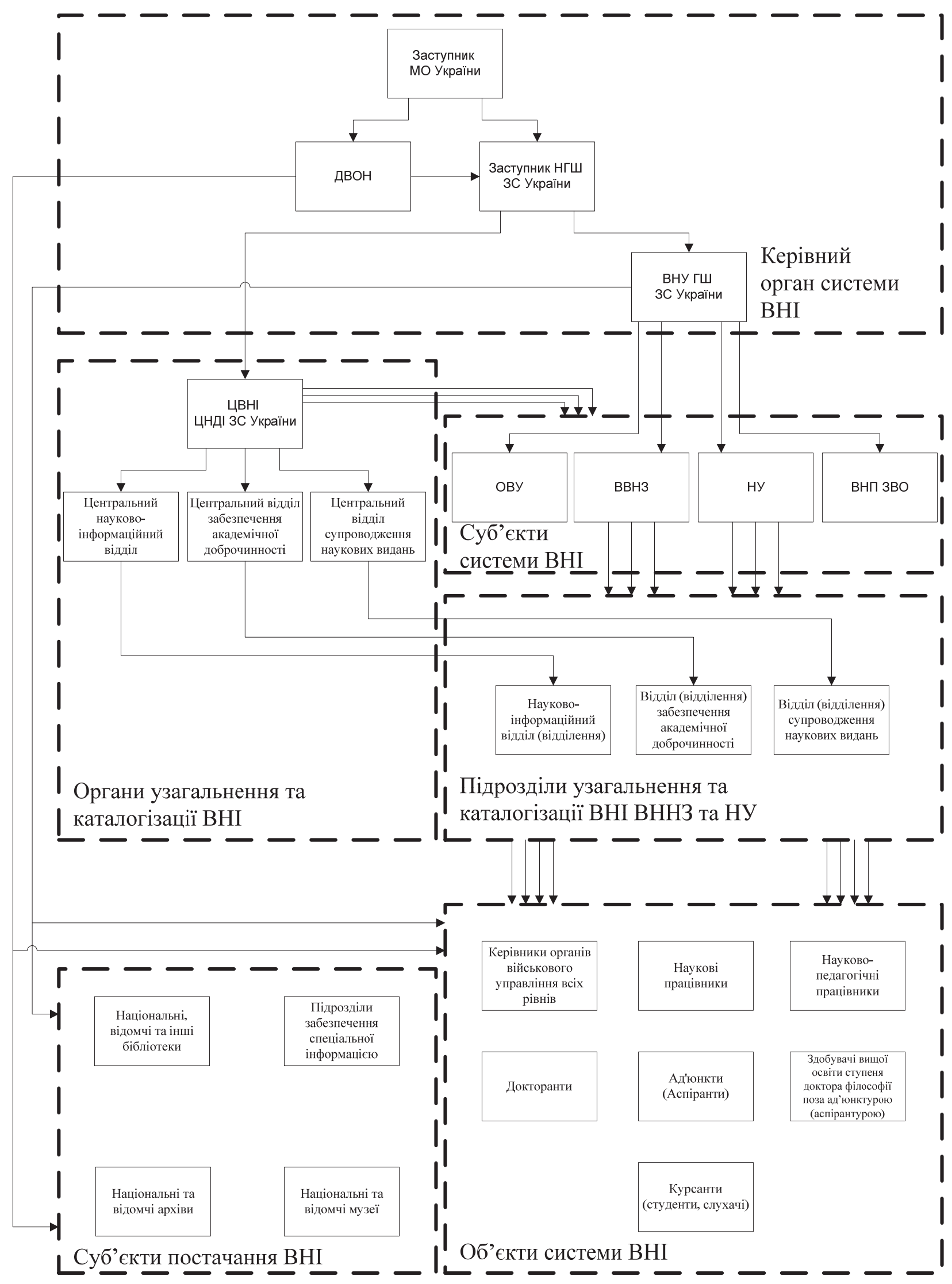

Рис. 1. Запропонована схема функціонування системи ВНІ ЗС України Джерело: розроблено авторами.

організація, контроль та впровадження заходів 3 удосконалення суб'єктами системи ВНІ інформаційного забезпечення НіНТД ЗС України; організація взаємодії між суб'єктами системи BНI, суб'єктами постачання системи ВНI, а також із державними органами науково-технічної інформації; 
розроблення, в межах компетенції, проектів наказів МО України та ГШ України, інших керівних документів 3 питань організації та ведення інформаційного забезпечення НіНТД у Збройних Силах України;

планування та організація (на основі зведених замовлень органів військового управління (ОВУ), ВВНЗ та НУ) передплати на інформаційні, наукові, науково-технічні та інші видання.

Головним органом узагальнення та каталогізації ВНІ $є$ центр воєнно-наукової інформації (ЦВНІ) Центрального науково-дослідного інституту (ЦНДІ) Збройних Сил України.

На ЦВНІ ЦНДІ Збройних Сил України покладаються такі завдання:

пошук, збір, оброблення, аналіз, збереження, видання та доведення до споживачів ВНI з питань науки і техніки в інтересах МО України та Збройних Сил України;

аналіз та систематизація інформаційних потоків, що циркулюють у системі ВНІ;

облік у МО України та Збройних Силах України науково-дослідних (дослідно-конструкторських) робіт, дисертацій, іншої науково-технічної продукції;

проведення наукових досліджень у галузі вдосконалення інформаційного забезпечення НіНТД Збройних Сил України та системи ВНІ Збройних Сил України, підвищення ефективності інформаційних процесів, функціонування системи ВНІ в цілому;

взаємодія 3 державними науково-інформаційними системами;

загальна координація дотримання академічної доброчесності та етики академічних взаємовідносин, як елементу внутрішньої системи забезпечення якості наукової діяльності в МО України та Збройних Сил України;

обгрунтування форм і способів просування новітніх знань та результатів фундаментальних, пошукових та прикладних наукових досліджень Збройних Сил України у міжнародному науковому середовищі;

участь у розробленні і впровадженні інформаційно-пошукових систем, технічних засобів оброблення ВНI, форм, методів і єдиних стандартів у рамках системи ВНI;

підготовка, видання та доведення до ОВУ, ВВНЗ, НУ та ВНП ЗВО наукових, інформаційних та довідкових матеріалів МО України та Збройних Сил України.

До суб'єктів системи ВНІ відносяться:

- органи військового управління всіх рівнів;

- науково-організаційні підрозділи всіх рівнів;

- науково-інформаційні підрозділи ВВНЗ, НУ;

- особи, відповідальні за функціонування системи спеціальної інформації.

3 метою ефективного функціонування системи ВНІ у ВВНЗ та НУ створюються три підрозділи уза- гальнення та каталогізації ВНІ ВВНЗ та НУ з різним функціональним призначенням:

- науково-інформаційний відділ (відділення);

- відділ (відділення) забезпечення академічної доброчинності;

- відділ (відділення) супроводження наукових видань.

На суб'єкти системи ВНІ покладаються такі завдання:

- інформаційне забезпечення, прийняття рішень посадовими особами МО України, Збройних Сил України, ГШ Збройних Сил України, командувачів видів (сил, військ), ВВНЗ, НУ, ВНП ЗВО з питань діяльності, розвитку, підготовки і застосування Збройних Сил України (в залежності від рівня підпорядкованості);

- інформаційне забезпечення НіНТД Збройних Сил України МО України, Збройних Сил України, ГШ Збройних Сил України, командувачів видів (сил, військ), ВВНЗ, НУ та ВНП ЗВО наукових досліджень і розробок у галузі теорії і практики збройної боротьби, розвитку ОВТ (у межах своїх повноважень за напрямом діяльності);

- дослідження 3 підвищення ефективності інформаційного забезпечення НіНТД Збройних Сил України;

- оперативне доведення до споживачів BНI результатів наукових досліджень, досягнень науки i техніки в Україні та поза її межами;

- індексування та каталогізація документів i матеріалів, оновлення бібліографічних та повнотекстових баз даних, формування за напрямами діяльності структурних підрозділів ВВНЗ, НУ та ВНП ЗВО розділів баз даних;

- забезпечення ефективної системи запобігання та виявлення академічного плагіату в наукових виданнях МО України та ГШ Збройних Сил України та роботах здобувачів наукових ступенів доктор філософії та доктор наук;

- редакційно-видавнича діяльність 3 випуску інформаційних, інформаційно-аналітичних, довідково-інформаційних, довідкових, наукових, навчальних та методичних видань (у межах своїх повноважень за напрямом діяльності).

До суб'єктів постачання системи ВНІ відносяться:

- національні, відомчі та інші бібліотеки;

- підрозділи забезпечення спеціальною інформацією;

- національні та відомчі архіви;

- національні та відомчі музеї.

На суб'єкти постачання системи ВНІ покладаються такі завдання:

- надання інформаційно-довідкових матеріалів за запитами суб'єктів системи ВНІ;

- зберігання та каталогізація баз даних ВНI; 
- надання спеціальної інформації.

До об'єктів ВНІ відносяться:

керівники органів військового управління всіх рівнів;

- наукові працівники;

- науково-педагогічні працівники;

- докторанти;

- ад'юнкти (аспіранти);

- здобувачі вищої освіти ступеня доктора філософії поза ад'юнктурою (аспірантурою);

- курсанти (студенти, слухачі).

До складу суб'єкту системи ВНІ за функціонально-тематичною ознакою можуть входити довідково-інформаційні фонди (ДІФ) суб'єкту системи ВНІ.

ДІФ суб'єкту системи ВНІ - сукупність упорядкованих документів і довідково-пошукового апарату, призначених для задоволення інформаційних потреб споживачів воєнно-наукової інформації суб'єкту системи ВНІ. Довідково-інформаційні фонди $є$ складовою національного науково-інформаційного ресурсу.

ДІФ суб'єкту системи ВНІ є інформаційною базою для своєчасного забезпечення структурних підрозділів суб'єкту системи ВНІ якісною, систематизованою і диференційованою ВНI, яка необхідна для прийняття рішень, проведення НіНТД суб'єкту системи ВНI.

Створення системи ВНІ за приведеною схемою дозволить наблизити систему ВНІ до системи НАТО та збройних сил США з врахуванням військовоцивільної побудови МО України та 3С України, визначити ієрархію між основними елементами системи ВНI, розмежувати сфери відповідальності органів військового управління, встановити напрямки взаємозв'язків між основними елементами системи BHI.

\section{Висновки}

Система інформаційного забезпечення НАТО та збройних сил США $є$ складовою їх цивільної структури. Характер побудови їх системи ВНІ обумовлений чітким розмежуванням між функціями військової структури, що займається виключно бойовою підготовкою та веденням бойових дій, та цивільною структурою, що займається адміністративними питаннями, НіНТД, залученням виключно невійськових підприємств організацій до проведення досліджень.

3 урахуванням специфіки побудови Збройних Сил України за військово-цивільною структурою, наявності в їі структурі ВВНЗ та НУ з великим науковим потенціалом та досвідом керівництва військовими організаційними структурами, що в значній зменшують фінансове навантаження при розробці нової науково-технічної продукції, сліпе копіювання структури НАТО та збройних сил США не доцільне.

3 метою уніфікації поняття, що застосовуються в НАТО, збройних силах США та Україні для інформації направленої на забезпечення наукових досліджень в Збройних Силах України запропоновано використовувати поняття “воєнно-наукова інформація".

Запропонована у роботі модель побудови системи ВНІ Збройних Сил України дозволяє врахувати позитивні риси системи ВНІ НАТО та збройних сил США, а також вдосконалити систему ВНІ Збройних Сил України. Це дасть можливість розмежувати сфери відповідальності органів військового управління та встановити напрямки взаємозв'язків між основними елементами системи ВНI.

\section{Список літератури}

1. Про наукову і науково-технічну діяльність : Закон України від 26.11.2015 р. № 848-VIII. Офіиійний вісник України. 12.01.2016. № 2. С. 19. Ст. 40. Код акта 80089/2015.

2. Про затвердження Положення про організацію наукової і науково-технічної діяльності в системі Міністерства оборони України : Наказ Міністерства оборони України від 27.07.2016 р. № 385. Офічійний вісник Украӥни. 16.09.2016. № 71. С. 117. Ст. 2397. Код акта 83033/2016.

3. Про затвердження Положення про науково-інформаційну діяльність у Збройних Силах України : Наказ Міністра оборони України від 27.09.2000 р. №315. URL: https://www.mil.gov.ua/content/gsc_orders (дата звернення 17.09.2021).

4. Про визначення такими, що втратили чинність, деяких наказів Міністра оборони України : Наказ Міністерства оборони України від 12.09.2016 p. №474. URL: https://www.mil.gov.ua/content/gsc_orders/MOU2016_474.pdf (дата 3вернення 17.09.2021).

5. Про затвердження Типових нормативів для розроблення штатів (штатних розписів) вищих військових навчальних закладів, військових навчальних підрозділів закладів вищої освіти та військових ліцеїв : Наказ Міністерства оборони України від 23.02.2018 р. № 82. Офіиійний вісник України. 04.05.2018. № 35. С. 56. Ст. 1239. Код акта 89992/2018.

6. Office of the under secretary of defense for research and engineering : веб-сайт. URL: https://www.cto.mil/ (дата звернення 17.09.2021).

7. Про науково-технічну інформацію : Закон України від 25.06.1993 p. №3322-XII. Відомості Верховної Ради України. 17.08.1993. № 33. Ст. 345.

8. Про інформацію : Закон України від 2.10.1992 р. № 2657-XII. Відомості Верховної Ради Украӥни. 01.12.1992. № 48. Ст. 650 .

9. ВСТ 01.101.004. Розвідувально-інформаційна діяльність. Терміни та визначення. Київ, 2015. 26 с. 
10. Тристан А. В., Крижанівський І. М., Мельник С. А., Горбут Є. М. Модель оцінювання інформаційних можливостей органів управління розвідкою. Системи озброєння $і$ військова техніка. 2020. № 1(61). С. 75-81. https://doi.org/ 10.30748/soivt.2020.61.09.

11. North atlantic treaty organization : веб-сайт. URL: https:/www.nato.int/cps/en/natolive/structure.htm (дата звернення 17.09.2021).

\section{Відомості про авторів:}

\section{Щербінін Сергій Олександрович}

кандидат технічних наук начальник науково-інформаційного відділення

Харківського національного університету

Повітряних Сил ім. І. Кожедуба,

Харків, Україна

https://orcid.org/0000-0003-0966-2476

\section{Беспалько Олена Валеріївна}

молодший науковий співробітник

Харківського національного університету

Повітряних Сил ім. І. Кожедуба,

Харків, Україна

https://orcid.org/0000-0002-5470-6450

\section{Гарячий Максим Володимирович}

помічник начальника науково-організаційного відділу

Харківського національного університету

Повітряних Сил ім. І. Кожедуба,

Харків, Україна

https://orcid.org/0000-0001-5177-6958

\section{Михальчук Юлія Романівна}

науковий співробітник

Харківського національного університету

Повітряних Сил ім. І. Кожедуба,

Харків, Україна

https://orcid.org/0000-0003-2367-4035
Information about the authors:

\author{
Serhii Shcherbinin \\ $\mathrm{PhD}$ in Engineering \\ Head of the Scientific and Information Department \\ of Ivan Kozhedub Kharkiv National \\ Air Force University, \\ Kharkiv, Ukraine \\ https://orcid.org/0000-0003-0966-2476
}

\author{
Olena Bespalko \\ Junior Researcher \\ of Ivan Kozhedub Kharkiv National \\ Air Force University, \\ Kharkiv, Ukraine \\ https://orcid.org/0000-0002-5470-6450
}

Maksim Gariachiy

Assistant Head of the Scientific and Organizational

Department of Ivan Kozhedub Kharkiv

National Air Force University,

Kharkiv, Ukraine

https://orcid.org/0000-0001-5177-6958

\author{
Yuliia Mykhalchuk \\ Researcher \\ of Ivan Kozhedub Kharkiv \\ National Air Force University, \\ Kharkiv, Ukraine \\ https://orcid.org/0000-0003-2367-4035
}

\section{МОДЕЛЬ СИСТЕМЫ ВОЕННО-НАУЧНОЙ ИНФОРМАЦИИ ВООРУЖЕННЫХ СИЛ УКРАИНЫ}

\section{С.А. Щербинин, Е.В. Беспалько, М.В. Гарячий, Ю.Р. Михальчук}

В работе рассматриваются вопросы информационного обеспечения научной и научно-технической деятельности НАТО, вооруженных сил США и Вооруженных Сил Украины. Приведен анализ структуры информационного обеспечения научной и научно-технической деятельности НАТО и вооруженных сил США. По результатам приведенного анализа выявлена нецелесообразность прямого копирования системы военно-научной информации в систему военно-научной информачии Вооруженных Сил Украины. На основе анализа руководящих документов и с иелью унификаџии понятия, применяемые в НАТО, вооруженных силах США и Украины для информачии, направленной на обеспечение научных исследований в Вооруженных Силах Украины, предложено использовать понятие “военно-научная информация”. Предложенная в работе модель системы военно-научной информации состоит из руководящего органа системы военнонаучной информации, органа обобщения и каталогизации военно-научной информации, субъектов системы военнонаучной информачии, подразделений обобщения и каталогизации военно-научной информации высших военных учебных заведений и научных учреждений, субъектов поставки военно-научной информации, объектов системы военно-научной информации. Эта система с административной точки зрения является иерархической и замкнутой. С точки зрения предоставления информации объектам военно-научной информации система имеет структуру созвездия, то есть любой элемент системы имеет право напрямую взаимодействовать с объектом военно-научной информации. Ограничения в предоставлении информации обусловливаются уровнем доступа объекта военно-научной информации к той или иной информации. Предложенная в работе модель системы военно-научной информации дает возможность разделить вертикаль информачионного обеспечения научной и научно-технической деятельности на структурные единицы по функииональному характеру, определить иерархию между основными элементами системы военно-научной информаиии, разграничить сферы ответственности органов военного управления, установить направления взаимосвязей между основными элементами системы военно-научной информации и в дальнейшем исследовать эффективность ее функционирования.

Ключевые слова: информация, военно-научная информачия, информационное обеспечение, техническая информачия, научная и научно-техническая деятельность. 
MODEL OF THE MILITARY AND SCIENTIFIC INFORMATION SYSTEM OF THE ARMED FORCES OF UKRAINE

S. Shcherbinin, O. Bespalko, M. Gariachiy, Y. Mykhalchuk

The article contain the issues of information support for scientific, scientific and technical activities of NATO, the US Armed Forces and the Armed Forces of Ukraine. The analysis of the structure of information support for scientific, scientific and technical activities of NATO and the US Armed Forces is given. Based on the results of the analysis, the inadvisability of direct copying of the military and scientific information system into the military and scientific information system of the Armed Forces of Ukraine was revealed. Based on the analysis of guidance documents and in order to unify the concepts used in NATO, the US and Ukrainian armed forces for information aimed at ensuring scientific research in the Armed Forces of Ukraine, it is proposed to use the concept of "military and scientific information". The proposed model of the military and scientific information system consists of the governing body of the system of military and scientific information, the body for generalizing and cataloging military and scientific information, subjects of the system of military and scientific information, subdivisions for generalizing and cataloging military and scientific information of higher military educational institutions and scientific institutions, subjects of supply of military and scientific information, objects of the system of military and scientific information. From an administrative point of view, this system is hierarchical and closed. From the point of view of providing information to objects of military and scientific information, the system has a constellation structure, that is, any element of the system has the right to directly interact with the object of military and scientific information. Restrictions in the provision of information are determined by the level of access of the object of military and scientific information to this or that information. The proposed model of the military and scientific information system makes it possible to divide the vertical information support of scientific, scientific and technical activities into structural units according to their functional nature, to determine the hierarchy between the main elements of the military and scientific information system, to delineate the spheres of responsibility of military command and control bodies, to establish directions interrelationships between the main elements of the military and scientific information system and further investigate the effectiveness of its functioning.

Keywords: information, military and scientific information, information support, technical information, scientific, scientific and technical activities. 